\title{
EFFECTS OF BENZODIAZEPINES AND NONBENZODIAZEPINES ON SLEEP QUALITY: A SYSTEMATIC REVIEW
}

Nelson Couto*, Luís Oliveira*, Eva Mendes*, Lúcia Ribeiro*

* Medical Doctor, Psychiatry Department, Vila Nova Gaia/Espinho Hospital Center, Portugal

\section{OBJECTIVES}

To characterize the impact that benzodiazepine and nonbenzodiazepine hypnotic molecules have on sleep architecture and structure, either subjectively through psychometric scales or through exams such as polysomnography.

\section{BACKGROUND}

Insomnia is a very prevalent medical condition, the incidence of which increases in older people. Pharmacological treatments are used in a large number of cases, among which are the drugs that bind to the GABAA (Type A gammaaminobutyric acid)receptor. The effects of these drugs on sleep quality remains controversial.

\section{MATERIALS AND METHODS}

The bibliographic search was performed using the terms "sleep" and "benzodiazepines" and "quality" in the databases MEDLINE (Medical Literature Analysis and Retrieval System Online), SciELO (Scientific Electronic Library Online) and Embase (Excerpta Medica dataBASE). Works prior to 1985 were excluded.

\section{RESULTS AND CONCLUSIONS}

After screening 1401 citations, 17 studies were included. Four studies evaluated sleep quality perceived by patients, with benzodiazepine users having worse scores than nonusers. Five other papers dealt with changes in polysomnography and detect a marked reduction of arousals associated with increased number of nocturnal awakenings without relevant modifications of sleep macroarchitecture. Users registered an increase stage 2, decrease stages 3 and 4 , and interfere with the production of slow-wave sleep, especially after repeated administration. Alternatively, the nonbenzodiazepine BzRAs (Benzodiazepine receptor agonists, frequently referred to as the Z-drugs) do not seem to consistently alter sleep stages. Although the short-term benefit of benzodiazepine use on sleep continuity is well documented, these drugs do not normalize sleep.

\begin{tabular}{|c|c|c|c|}
\hline FIRST AUTHOR & YEAR & TITLE & JOURNAL \\
\hline Bastien, C. H. & 2003 & $\begin{array}{l}\text { Sleep EEG power spectra, insomnia, } \\
\text { and chronic use of } \\
\text { benzodiazepines(6) }\end{array}$ & Sleep \\
\hline Beland, S. G. & 2010 & $\begin{array}{l}\text { Benzodiazepine use and quality of } \\
\text { sleep in the community-dwelling } \\
\text { elderly population(7) }\end{array}$ & $\begin{array}{l}\text { Aging Ment } \\
\text { Health }\end{array}$ \\
\hline Bourgeois, J. & 2013 & $\begin{array}{l}\text { Sleep quality of benzodiazepine } \\
\text { users in nursing homes: a } \\
\text { comparative study with nonusers(8) }\end{array}$ & Sleep Med \\
\hline Bourgeois, J. & 2014 & $\begin{array}{l}\text { One-year evolution of sleep quality in } \\
\text { older users of benzodiazepines: a } \\
\text { longitudinal cohort study in belgian } \\
\text { nursing home residents(9) }\end{array}$ & Drugs Aging \\
\hline Chen, L. & 2016 & $\begin{array}{l}\text { The association between } \\
\text { benzodiazepine use and sleep quality } \\
\text { in residential aged care facilities: a } \\
\text { cross-sectional study }(10)\end{array}$ & BMC Geriatr \\
\hline Hein, M. & 2018 & $\begin{array}{l}\text { Objective sleep alterations and long- } \\
\text { term use of short or intermediate } \\
\text { half-life benzodiazepine receptor } \\
\text { agonists are risk factors for high } \\
\text { blood pressure in individuals with } \\
\text { insomnia: a study in } 1272 \text { individuals } \\
\text { referred for sleep examinations(11) }\end{array}$ & Sleep Med \\
\hline $\begin{array}{l}\text { Holbrook, A. } \\
\text { M. }\end{array}$ & 2000 & $\begin{array}{l}\text { Meta-analysis of benzodiazepine use } \\
\text { in the treatment of insomnia(5) }\end{array}$ & CMAJ \\
\hline $\begin{array}{l}\text { Huedo- } \\
\text { Medina, T. B. }\end{array}$ & 2012 & $\begin{array}{l}\text { Effectiveness of non-benzodiazepine } \\
\text { hypnotics in treatment of adult } \\
\text { insomnia: meta-analysis of data } \\
\text { submitted to the Food and Drug } \\
\text { Administration(12) }\end{array}$ & BMJ \\
\hline Kanii, S. & 2016 & $\begin{array}{l}\text { Pharmacological interventions to } \\
\text { improve sleep in hospitalised adults: } \\
\text { a systematic review(13) }\end{array}$ & BMJ Open \\
\hline Manconi, M. & 2017 & $\begin{array}{l}\text { Sleep architecture in insomniacs with } \\
\text { severe benzodiazepine abuse(14) }\end{array}$ & $\begin{array}{l}\text { Clin } \\
\text { Neurophysiol }\end{array}$ \\
\hline Mazza, M. & 2014 & $\begin{array}{l}\text { Polysomnographic findings in a } \\
\text { cohort of chronic insomnia patients } \\
\text { with benzodiazepine abuse(15) }\end{array}$ & J Clin Sleep Med \\
\hline Mellinger, G. D. & 1985 & $\begin{array}{l}\text { Insomnia and its treatment. } \\
\text { Prevalence and correlates }(1)\end{array}$ & $\begin{array}{l}\text { Arch Gen } \\
\text { Psychiatry }\end{array}$ \\
\hline Riemann, D. & 2017 & $\begin{array}{l}\text { European guideline for the diagnosis } \\
\text { and treatment of insomnia(2) }\end{array}$ & J Sleep Res \\
\hline Schroeck, J. L. & 2016 & $\begin{array}{l}\text { Review of Safety and Efficacy of } \\
\text { Sleep Medicines in Older Adults(16) }\end{array}$ & Clin Ther \\
\hline Wagner, J. & 2000 & $\begin{array}{l}\text { Non-benzodiazepines for the } \\
\text { treatment of insomnia(4) }\end{array}$ & Sleep Med Rev \\
\hline Wick, J. Y. & 2013 & The history of benzodiazepines(3) & Consult Pharm \\
\hline
\end{tabular}

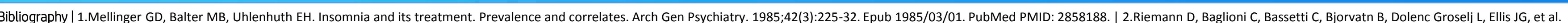

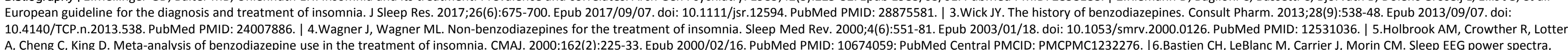

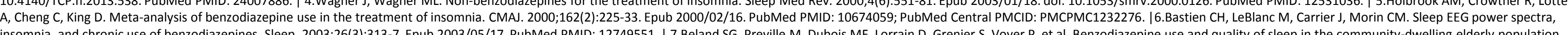

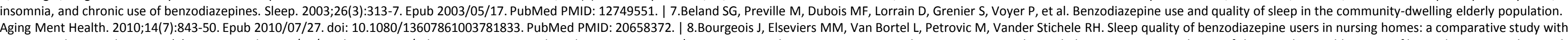

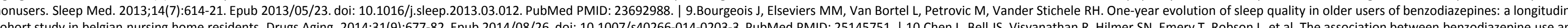

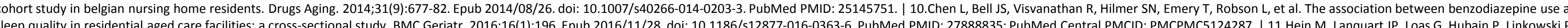

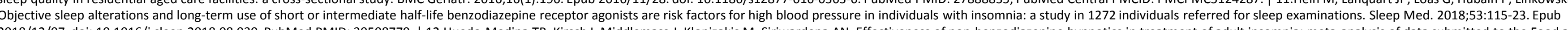

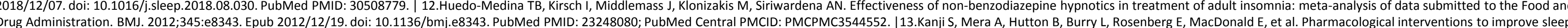

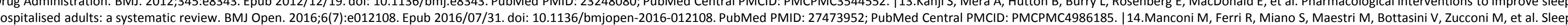
achitecture in insomniacs with severe benzodiazepine abuse. Clin Neurophysiol. 2017;128(6):875-81. Epub 2017/04/12. doi: 10.1016/j.clinph.2017.03.009. PubMed PMID: 28399441. |15. Mazza M, Losurdo A, Testani E, Marano G, Di Nicola M, Dittoni S, et al. Polysomnographic 作 